УДК 316.752:321.011.5]:001.8

Nagorniak K.M., post-graduate student, National University of "Kyiv-Mohyla Academy"

\title{
SCALES OF DEMOCRATIC VALUES: MEASUREMENT INVARIANCE IN POST-SOCIALIST SOCIETIES
}

\begin{abstract}
Investigation of democracy is needed to understand the changing process in each country. At the same time analysis of values dynamic is not efficient without evaluation of similarities and sustainable measurement of constructs. It means that in order to compare different indicators of values derived from surveys of heterogeneous samples, it is important to evaluate measurement invariance of indicators of values (measurement equivalence). The purpose of the article is overview of methodological problem of measurement invariance, specifically scales of democratic values. This article includes approaches of studying the concept of democratic value generalized definition of the concept of democratic orientation values and their components. Overview of the literature gives possibility to find the gap in the field study and propose the own view of further research.
\end{abstract}

Keywords: democracy; democratic values; measurement invariance; multi-group confirmatory factor analysis.

According to the theory of modernization [1] less developed countries have to pass the same phases of development as more developed societies. At the same time, economic development (based on GDP) should be accompanied by the improvement of living standards. However, the model of «GDP growth - improving the quality of life», does not work every time. In fact, non-economic indicators should be taken into account to describe and explain the public mood. For example, there are cultural values. According to the rese arch, in a longitudinal perspective, social values can be changed with economic development transmitted from one generation to another. Wealthy postindustrial societies show large intergenerational differences. It means that the younger cohorts are generally calling more attention on modern attitudes than the older cohorts [2].

At the same time, it is always questionable how to compare different indicators of values derived from surveys of heterogeneous samples, especially in international surveys. As the result, comparison value indices may lead to inaccurate results due to different structures in different samples. In this regard, there are sets of methods to verify the comparability of indicators based on the study of invariant structure indicators of latent variables.

It is important to note that latent variables are the cause of indicators, which are interpreting the association among the observed variables. That is why it is significant to search for a general latent factor, which consists of several variables and then explain and investigate each variable separately.

Democracy is an example of a political regime in which power is delegated to people by representatives (directly or indirectly). In order to make a democratic system functioning and to affect positively all areas of public life, it is necessary to develop and follow related to a regime values, e.g. values of freedom, self-expression, autonomy, equality and so on. Democratic values that are predominant in society influence further development. In fact, this tendency is transmitted from one generation to another.

Some analysts claim that the world has entered a «democratic recession». Others argue this interpretation emphasizing democracy's success in maintaining the huge gains it made during the last 
quarter of the $20^{\text {th }}$ century [3]. Since the late 1990s, democracy has broken down in Russia, Nigeria, Venezuela, the Philippines, Pakistan, Bangladesh, Thailand, and Kenya [4]. According to Freedom House, in 2012, autocratic regimes in Eurasia fought energetically to keep the threat of democratic change at bay [5]. In some cases, governments with established records of repression introduced new and arguably redundant measures to further constrain dissent, having already engaged in years of censorship, subjugated the justice system, and in some contexts resorted to violence. As a result, governance institutions in the region's autocracies grew more dysfunctional, less independent, and more prone to corruption.

In addition, the year of 2013 was the eighth consecutive year when more countries experienced declines in political rights or civil liberties than improvement. According to its regime type, Ukraine is a country with transitional government or the country with hybrid regime. It is the position in the middle of the scale of democracy between consolidated democracy and consolidated authoritarian regime (democracy score: 4.75). The democracy scores and regime ratings are based on a scale from 1 to 7 , with 1 representing the highest level of democratic progress and 7 - the lowest [6].

Nonetheless, in the long run, economic development, globalization, and the growth of civil society will induce democratic change in a number of autocracies, including China and Vietnam. Yet, it is important to note that democracy should be reformed and revived in the world's key swing states [4]. Debates on democratization explore the issues of democratic consolidation and its alternatives from the point of view of democratic governance and stability [7].

At the same time, investigation of democracy is needed to understand the processes of changes in each country. As it was mentioned earlier, democracy is declining in the world. Moreover, it is worth taking into consideration that post-socialist countries have the legacy of authoritarian regime. In order to change the decline process and to find the tools for influence regression of democracy, the changing of attitude towards democracy (values of democracy) should be considered as a phenomenon through age cohorts.

Yet, investigation of dynamic of values is not efficient without analysis of similarities and sustainable measures of constructs. It means that in order to compare different indicators of values derived from surveys of heterogeneous samples, it is important to evaluate measurement invariance of indicators of values (or measurement equivalence). This is a particularly crucial when compared to values and relationships of latent variables, often measured indices. In particular, validity as functioning of the same indicators in different measurement conditions is often omitted in different international surveys [8].

Also, indicators of latent variable (e.g. value of security) may operate differently. It means that they may have different structure correlations in different populations (countries). That is why the lack of invariance leads to incorrect comparison of values and connections of latent variable in these populations.

It is worth to note that the main problem of invariance occurs as the question of measurement operations. Measurement invariance refers to «whether or not, under different measurement operations yield measures of the same attribute». If evidence supporting a measure's invariance is lacking, conclusions based on that scale are at best ambiguous and at worst erroneous [9].

The purpose of the article is a preview of investigation of measurement invariance methodological problem, specifically of scales of democratic values in post-socialist countries. In other words, the aim is evaluation the possibilities of latent variables comparison by checking the equality of factor measuring models that include factor loadings, indicator intercepts, their error variances and relationships between latent variables in the various samples.

In fact, the problem of comparability of the data is particularly acute because of questions, which were given to respondents in different languages in different socio-cultural contexts. For international 
studies such as European Social Survey (ESS), International Social Survey Program (ISSP), World and European Values Survey (WVS/EVS), and many others, the problem of understanding questions and meaning of indices (latent variables) are crucial in order to compare answers across different societies.

The comparability of cross-national surveys is challenged by various methodological problems like translation and differences in survey practice that affect the sampling and coverage [10]. This challenge increases as one expands the number of countries that are included in the survey. To date, the WVS is the only academic (nearly) global public opinion survey that covers over $80 \%$ of the world population. While the WVS collects data in face-to-face interviews using standardized sampling methods, the standardization is still limited. This limitation underlines the importance of testing for invariance of the scales used across countries [10].

According to the study (focused on this problem), the scales that measure attitudes toward democracy may be compared, but only to a certain extent and not across all the countries. In fact, the authors examine the cross-cultural equivalence of two scales across 36 countries in the World Value Survey (WVS) 2000. They observe the equivalence of these scales in order to explore if one can meaningfully compare democratic attitudes across countries [10].

In fact, there are several studies that investigate basic life values, which are defined by Schwartz. His theory postulates the existence of the same values, which can be measured equally well among people from different cultures and countries [11]. Yet, in each ESS round of survey research team include basic life values Schwartz and try to change formulation of measurement tools based on the problem of invariance. That is why they including only those indicators that showed their comparability in at least small number of countries. However, one of the recent modifications of the method of Schwartz is able to measure only a small number of values and not all countries can be compared in ESS [12].

In addition, a lot of studies rely on a single measure (e.g., scale score, one indicator which consists of only one item etc.) of a given construct for each person in each occasion of measurement, assuming that measure reflects the same construct in each occasion. With multiple indicators of a latent construct at each time of measurement, the researcher can evaluate whether factorial invariance holds. If factorial invariance constraints are satisfied, latent variable scores at each time of measurement are on the same metric and stronger conclusions are warranted [13].

The importance of investigation of democracy. Since 1974, more than 90 countries have made transitions to democracy, and by the turn of the century approximately 6o percent of the world's independent states were democratic. The democratization of Mexico and Indonesia in the late 1990s and the more recent «color revolutions» in Georgia and Ukraine formed the crest of a tidal wave of democratic transitions [14].

However, according to scientist's view, after decades of the world has slipped into a democratic recession because of existing predatory states which are threatening both nascent and established democracies throughout the world. This trend can be reversed with the development of good governance and strict accountability and the help of conditional aid from the West [14].

Based on the study ${ }^{1}$, which investigated the correlation between country growth and democracy (subjective indexes of political freedom), there is a suggestion of a nonlinear relationship in which more democracy enhances growth at low levels of political freedom, but depresses growth when a moderate level of freedom has already been attained. The favorable effects on growth include maintenance of the rule of law, free markets, small government consumption, and high human capital.

\footnotetext{
${ }^{1}$ There is analyzed for a panel of about 100 countries from 1960 to 1990.
} 


\section{ISSN 1681-116X. Український соціум. 2016. № 1(56)}

Once these kinds of variables and the initial level of real per capita GDP are held constant, the overall effect of democracy on growth is weakly negative. Improvements in the standard of living, measured by GDP, health status, and education, substantially raise the probability that political freedoms will grow. These results allow for predictions that countries will become more or less democratic over time [15].

Democracy promotion has become increasingly acceptable as a foreign policy goal throughout most of the international communities [16]. It means that democracy as an international norm is stronger today than ever, and democracy itself is widely regarded as an ideal system of government.

What is important to note, is that democracy also has near-universal appeal among people of every ethnic group, every religion, and every region of the world. Throughout the world, people are embracing democracy not only as a system of government, but also as a value. At the same time, some leaders in some autocratic regimes try to defend their go-slow approach to political liberalization by arguing that their citizenry is not ready for democracy [16]. In fact, democracy is associated with a value.

According to Inglehart and Welzel, the main attention of the modernization theory is directed to changes in social values that have reflection on culture, economy, and politics. In fact, there are two main values which they offer to considerate as the key indicators of social development. The one value concerns materialistic aspects of social progress, such as the importance of survival. The other one is related to post-materialistic values which are connected with more mature stage of social growth such as self-expression [2].

Based on the relevant data, the authors argue that the values of developing countries differ from the values of transitional societies, as in the latter the dominant values are materialistic values. The designed indicator of post-materialist values contains high level of personal well-being and democracy as opposed to materialistic values, which include the importance of a career and financial satisfaction. According to the concepts, values are passed through generations. If for one generation economic and physical security (survival) is important, then another one has an increasing emphasis on selfexpression, subjective well-being and quality of life [17].

The study that represents analysis of human values in a longitudinal perspective has stated that wealthy post-industrial societies show large intergenerational differences with the younger cohorts than the older cohorts do. In contrast, low-income societies that have not experienced substantial economic growth during the past five decades do not display intergenerational differences.

Based on the results of Inglehart's study, the younger cohorts generally place much stronger emphasis on secular-rational values and self-expression values in post-industrial societies. However, in pre-industrial and industrial societies, the younger and older cohorts are about equally likely to display traditional or modern values [2].

The authors have suggested that these intergenerational differences display historical changes rather than anything inherent in the human life cycle. In fact, the generational distinctions reflect features of conditions in two different cohorts. As the authors have summarized, the intergenerational differences found in post-industrial societies seem to reveal the long-term socioeconomic changes resulting from the economic miracles that have occurred during the decades after World War II [2].

Consequently, long-term changings in economic and political spheres have influenced socioculture conditions. Therefore, two aged cohorts may have absolutely different attitudes, desires and even values.

For example, the study, conducted by R. Inglehart, P. Norris and C. Welzel, analyzes the role of changing mass attitudes in the spread of democratic institutions, using survey evidence from 70 societies containing 80 percent of the world's population. The evidence supports the conclusion 
that the process of modernization drives cultural change that encourages both the rise of women in public life, and the development of democratic institutions [18].

In addition, the spread of values is not limited by region within one country. For instance, the striking cultural similarities rather than differences were revealed in political values among the public living in Eastern and Western Ukraine. Ukrainians in both regions display the typical characteristics of «critical citizens" found in many parts of the world [19]. The low confidence toward core political institutions is also far from unique to this country [20].

To sum up, it is important to note that investigation of democracy gives possibility to monitor changes of people's attitudes to democratic orientations of their country and to predict future development society. These predictions help to rapidly react on political, socioeconomic situation within country, according to situation in other societies.

Measuring attitudes toward democracy in the WVS. According to the World Values Survey database that is a global network of social scientists studying changing values and their impact on social and political life, respondents are given statements that describe political system in the best way. In fact, respondents check each statement based on their opinion and estimation of the way of governing this country (very good, fairly good, fairly bad or very bad way of governing this country). It should be noted that one of these systems is related to democratic ${ }^{2}$.

The WVS contains various items that capture different aspects of democratic attitudes such as satisfaction with democracy performance in the country, as well as questions inquiring different characteristics of democracy. Among these items, different rounds of the WVS contain two sets of items that were applied in various studies to measure two scales of democratic attitudes: the «democracy-autocracy preference» (DAP) scale and, what scientists labeled the «democratic performance evolution» (DPE) scale [10].

The first indicator with items is based on the question: "I am going to describe various types of political systems and ask what you think about each way of governing this country. For each, would you say it is a very good, fairly good, fairly bad, or a very bad way of governing this country?»:

- Having a strong leader who does not have to bother with parliament and elections;

- Having experts, not government, make decisions according to what they think is best for the country;

- Having the army rule;

- Having a democratic political system.

In general, this scale examines people's preferences of various types of political systems for their countries which were used in various studies to create what Inglehart and Welzel labeled as the DAP scale [2].

These indicators may be used as the first indicator of citizens' view of the way of governing their country to stress out the direction of public opinion.

The second set of items is based on the question: "I'm going to read off some things that people sometimes say about a democratic political system. Could you, please, tell me if you agree strongly, agree, disagree or disagree strongly, after I read each one of them?»:

- In democracy, the economic system runs badly;

- Democracies are indecisive and have too much quibbling;

- Democracies aren't good at maintaining order;

- Democracy may have problems but it's better than any other form of government.

Three items reflect respondent's evaluation of democratic performance which labels these four items as the democratic performance evolution (DPE) scale.

\footnotetext{
${ }^{2}$ Official Questionnaire of the World Values Survey (WV6, WVS 2010-2012), available at : http://www.worldvaluessurvey.org/WVSDocumentationWV6.jsp.
} 
ISSN 1681-116X. Український соціум. 2016. № 1(56)

It is important to note that these items of the DAP scale were included in three waves of the WVS (1995, 2000, 2005), the DPE scale in the 1995 and 2000 WVS waves.

The other question, which is used in this survey, relates directly to the characteristics of democracy that respondents should estimate as essential or not essential for this political system based on their view (using scale from 10 to 1 respectively):

- Governments tax the rich and subsidize the poor;

- Religious authorities ultimately interpret the laws;

- People choose their leaders in free elections;

- People receive state aid for unemployment;

- The army takes over when government is incompetent;

- Civil rights protect people from state oppression;

- The state makes people's incomes equal;

- People obey their rulers;

- Women have the same rights as men.

The additional questions of understating people's attitude are:

- How important is it for you to live in a country that is governed democratically?

- And how democratically is this country being governed today?

- How much respect is there for individual human rights nowadays in this country? Do you feel there is:

- A great deal of respect for individual human rights;

- Fairly much respect;

- Not much respect;

- No respect at all?

These questions may be used for constructing the index of democratic values because they are outlining the general view what is a democracy for people. In practice, there is set of introductory questions to start the list of items.

Speaking about the indicators of self-expression values, we should continue the overview of Inglehart's approach to measure the dimension of values.

Hence, he has outlined opposite «self-expression-survival values» which is indicated with the set of statements [21]:

- Respondent gives priority to self-expression and quality-of-life over economic and physical security;

- Respondent describes self as very happy;

- Respondent has signed and would sign a petition;

- Homosexuality is justifiable;

- You can trust people.

Honestly, this list of indicators is not comprehensive and final because this set of statements does not include other characteristics of personal intentions to self-expression. Therefore, it is necessary to fill it in based on the further literature review exploring and adopting instruments.

Approaches of measurement invariance in cross-national surveys. Comparing constructs across countries meaningfully requires determining whether the measurement characteristics of the relevant constructs are invariant across nations. Only if such equivalence is established researchers can make meaningful and clearly interpretable cross-national comparisons of the constructs and their associations with other variables [22].

Differences in scales means or in relationships (regression coefficients, covariances) between scales and other theoretical constructs of interest may derive from systematic biases of responses across countries or from variant understandings of the question items rather than from «true» 
differences across groups. Although current cross-national surveys take great care in item selection, translation, and other procedures in order to increase the probability of comparability of concepts across countries, these procedures cannot guarantee invariance, which requires statistical testing [10].

The empirical study of the causes and consequences of political democracy has been the subject of comparative research. Yet, this research is hampered by the controversial aspects and limitations of the existing indices of political democracy. These issues concern the validity of the indicators, the unknown reliability, and the limited sample and temporal coverage of these indices [23]. This is a particularly critical question how to compare values and relationships of latent variables because differences in the structure of the indices on different samples may lead to false results [24].

Modeling democracy as a latent variable allows assessing the «noise» (measurement error) in the resulting measure [25]. The study showed that this measurement error is considerable and has substantive consequences when using a measure of democracy as an independent variable in crossnational statistical analyses.

The movement toward democratic political systems in many nations in the 1980s has renewed interest in measurement of political democracy. The main conceptual problems are the failure to develop an adequate theoretical definition of this concept, the confounding of the concept with others, and treating democracy as a binary rather than a continuous concept. Four problems of measurement are: invalid indicators, subjective indicators, ordinal or dichotomous measures, and the failure to test reliability or validity. The study offers several suggestions to improve measurement as well as the warning about the danger of repeating past errors [23].

It is worth mentioning that examination of invariance is a necessary condition for comparing the means across countries. It finds confirmation, for example, in studies on national identity differentiate between nationalistic attitudes and constructive patriotism as two more specific expressions of national identity and as theoretically two distinct concepts. After a brief discussion of the theoretical literature, the authors examined the questions «Is their meaning fully or partially invariant across countries?» and «Is it possible to compare their means across countries?» [22].

Data from the International Social Survey Program (ISSP) 2003 National Identity Module are utilized to answer these questions in a sample of 34 countries. Items to measure nationalism and constructive patriotism are chosen based on the literature, and a series of confirmatory factor analyses to test for configural, measurement (metric), and scalar invariance are performed. Full or partial metric invariance is a necessary condition for equivalence of meaning across cultures and for a meaningful comparison of associations with other theoretical constructs. Findings reveal that nationalism and constructive patriotism emerge as two distinct constructs. However, in some countries some items that were intended to measure one construct also measure the other construct. Furthermore, configural and metric invariance are found across the full set of 34 countries. Consequently, researchers may now use the ISSP data to study relationships among nationalism, constructive patriotism, and other theoretical constructs across these nations [22].

Confirmatory factor analysis (CFA) is used in order to assess the measurement model in each country in the sample, as well as to examine the comparability of the scale across countries. CFA provides estimates of the relations between observed indicators and the hypothesized latent construct (factor), and provides fit indices that report whether the hypothesized structure of associations between a latent construct and its proposed indicators fits the data. This information is used to determine whether a hypothesized latent construct underlies a scale. Assuming the existence of a latent variable means that observed variables are only correlated to the extent that they share an underlying concept [10]. In fact, latent variables can be explained in terms of classical test theory, which states that any measure is a function of two components: true score variation and error variation. The concept of the latent variable from confirmatory factor analysis and structural equation 
modeling can be viewed in parallel to the classical test theory formulation. The latent variable is like a true score that is not directly observed, the observed variable is the measurement that is directly observed, and some degree of random measurement error may exist such that the observed score does not perfectly match the true scores. As opposed to traditional indicators, latent variable helps to combine a set of variables which explains research phenomenon.

In fact, there are the three main types of invariance such as configural, metric, and scalar invariances which are generalized in one method multi-group confirmatory factor analysis (MCFA).

For demonstrating how the model of MCFA works it gives example. In fact, there are studies which verify how works invariance of Schwartz's values (ten basic values). For instance, to measure the basic values it was developed several questionnaires. One of them is «Portrait questionnaire» that consisting of 21 portraits with 6-point scale ranging from «very similar» to «not at all like me». The questionnaire has been created for use in the mass surveys of the European Social Survey (ESS). Ideally, this survey provides a measure of all the 10 values [24].

However, studies invariance among different countries and time points showed slightly different results. Several studies demonstrated that metric invariance is confirmed by a small circle of countries. In addition, the model had to be upgraded with a few cross-loadings and some values had to be strengthened. In result, factor model (with 7 factors) included combining values of 1) universalism and benevolence («Caring about people and nature»); 2) achieving wealth and power(«Assertiveness»); 3) conformity and tradition; 4) independence; 5) risk-novelty; 6) hedonism and 7) security. Only the Benelux countries have demonstrated scalar invariance model with 7 aggregated values. Later, in the second round of data ESS, scientists confirmed the 7-factor model metric invariance among 14 countries and scalar invariance between rounds, but only for nine countries [24]. It means that existing constructs are not comparable for each country in WVS. That is why it is important to formulate such indicators which will be suitable for all societies or specific of them.

In particular, it is important to note that lack of proving of scalar invariance of values means that comparison of mean of values for countries is incorrect. That is why in this case it is necessary to use other approaches of MCFA and comparison of average of values for these indicators should be omitted.

In Rudnev's study the model of MCFA has been tested on Russian-speaking populations such as Russia, Latvia, Estonia, Lithuania and Ukraine because previous studies did not include these countries in the investigation of invariance of indicators of values. In such studies, countries, where questions were not asked in English, were omitted. That is why European countries which satisfied this criterion were selected. In this sense proposed study may contribute new information about postsocialist countries, which are less presented in international comparative studies.

In addition, methodological finding of Rudnev's research is the fact that Russian-speaking group demonstrates the absence of a full scalar invariance due to changes in the wording. For example, replacing one or two words resulted in emergence of differences in the estimates of these portraits, which, in turn, reflected in the problems of measurement invariance of the latent constructs.

The method for testing measurement invariance is important a tool for working with international data because it provides information about the possibilities of comparison of latent variables.

It is significant to note that measurement invariance ensures an equal definition of a latent construct over time; that is, each indicator with the same surface characteristics (i.e., identical scaling and wording) must relate to the underlying construct in the same fashion over time.

Talking about evaluating factorial invariance across time there is approach that is adapted to evaluating factorial invariance in longitudinal contexts [26]:

- configural invariance: the same pattern of fixed and free factor loadings across time;

- weak factorial invariance: invariant factor loadings across time; 
- strong factorial invariance: invariant factor loadings and incepts across time;

- strict factorial invariance: invariant factor loadings, intercepts, and unique factor variances across time.

Conclusion. This article includes approaches of studying the concept of democratic value generalized definition of the concept of democratic orientation values and their components. Firstly, the author gave the definition of democracy (the brief overview of the concept). Secondly, according to existing studies, paper presented conceptualization of democratic values and their components. Thirdly, the construct of democratic values and their indicators was shown in order to give operationalization of concepts. Finally, in the end of the review, the idea of measurement invariance of scales of democratic values was illustrated as the method of assessment of similarity measurement values of democracy with the example of post-socialist countries.

Overview of the literature gives possibility to find the gap in the field study and propose the own view for further research. The purpose of the future study will be the assessment of measurement invariance of scales of democratic values in post-socialist countries.

\section{References}

1. Huntington S.P. Political Order in Changing Societies. New Haven: Yale University Press, 1968.

2. Inglehart R., Welzel C. Modernization, cultural change, and democracy. New York: Cambridge, 2005.

3. Diamond L., Plattner M.F. Democracy in decline? Journal of democracy, Vol. 26, No. 1, 2015.

4. Diamond L. Democracy's deeping reccession, 2014, available at: http://www.theatlantic.com/ international/archive/2014/05/the-deepening-recession-of-democracy/361591/

5. Freedom House: Freedom in the World Reports, 2013, available at: https://freedomhouse.org/ report/nations-transit/nations-transit-2013

6. Freedom House: Freedom in the World Reports, 2015, available at: https://freedomhouse.org/ report/nations-transit/nations-transit-2015\#.VguoReztmkp

7. Diamond L., Plattner M.F., Costopoulos P.J. Debates on Democratization. Johns Hopkins University, 2010.

8. Horn J.L., McArdle J.J. A Practical and Theoretical Guide to Measurement Invariance in Aging Research. Experimanetal Aging Research, 1992, No. 18 (3), pp. 117-144.

9. Steenkamp J.-B., Baumgartner H. Assessing Measurement Invariance in Cross National Consumer Research. Journal of Consumer Research, 1998, Vol. 25, Issue 1, pp. 78-90.

10. Ariely G., Davidov E. Can we Rate Public Support for Democracy in a Comparable Way? Cross-National Equivalence of Democratic Attitudes in the World Value Survey. Social Indicators Research, 2011, Vol. 104, No. 2, pp. 271-286.

11. Schwartz S.H. Universals in the Content and Structure of Values: Theoretical Advances and 20 Countries. Advances in Experimental Social Psychology, 1992, Vol. 25, pp. 1-62.

12. Davidov E. Cross-Country And Cross-Time Comparison Of The Human Values Measurements With The Second Round Of The European Social Survey. Survey Research Methods, 2008, Vol. 2, Issue 1, pp. 33-46.

13. Widaman K.F., Ferrer E., Conger R.D. Factorial Invariance within Longitudinal Structural Equation Models: Measuring the Same Construct across Time. Child Dev Perspect, 2010, Vol. 4, Issue 1, pp. 10-18.

14. Diamond L. The Democratic Rollback: The Resurgence of the Predatory State. Foreign Affairs, 2008, March/April, pp. 36-48.

15. Barro R.J. Democracy and growth. Journal of Economic Growth March, 1996, Vol. 1, No. 1, pp. 1-27.

16. McFaul M. Democracy promotion as a world value. The Washington Quarterly, 2004, pp. 147-163. 
ISSN 1681-116X. Український соціум. 2016. № 1(56)

17. Inglehart R., Baker E. Modernization, cultural change, and the persistence of tradional values. American Sociological Review, 2000, Vol. 65, pp. 19-51.

18. Inglehart R., Norris P., Welzel C. Gender Equality and Democracy. Comparative Sociolgy, 2002, Vol. 1, Issue 3-4, pp. 321-345.

19. Norris P. Democratic Deficit: Critical Citizens Revisited. New York: Cambridge University Press, 2011.

20. Norris P. The depth of Ukrainian divisions between east and west? 2014, March 3, available at: http://pippanorris.typepad.com/pippa_norris_weblog/2014/03/the-depth-of-ukrainian-divisionsbetween-east-and-west.html

21. Lacatos Z. Traditional values and the Inglehart constructs. Public Opinion Quarterly, 2015, Vol. 79, Special Issue, pp. 291-324.

22. Davidov E. Measurement Equivalence of Nationalism and Constructive Patriotism in the ISSP: 34 Countries in a Comparative Perspective Political Analysis, 2009, Vol. 17, Issue 1, pp. 64-82.

23. Bollen K.A. Political Democracy: Conceptual and Measurement Traps. Studies In Comparative International Development, 1990, Vol. 25, pp. 7-24.

24. Rudnev M.G. Invariantnost' izmereniya bazovykh tsennostei po metodike Shvartsa sredi russkoyazychnogo naseleniya chetyrekh stran [Measurement invariance of basic human values assessed with Schwartz instrument among four Russian-speaking populations]. Sotsiologiya: $4 M-$ Sociology: methodology, methods, mathematical modeling, 2013, No. 37, pp. 7-38 [in Russian]

25. Treier S. Democracy as a Latent Variable. American Journal of Political Science, 2008, Vol. 52, Issue 1, pp. 201-217.

26. Widaman K.F., Ferrer E., Conger R.D. Factorial Invariance within Longitudinal Structural Equation Models: Measuring the Same Construct across Time. Child Dev Perspect, 2010, Vol. 4, Issue 1, pp. 10-18.

Отримано 04.02.16 
Нагорняк К.М., аспірант кафедри соціології Національного університету «Києво-Могилянська академія», фахівець 3 управління проектами ГО «Український інститут соціальних досліджень імені О. Яременка» (Київ).

\section{ШКАЛИ ДЕМОКРАТИЧНИХ ЦІННОСТЕЙ: ВИМІРЮВАННЯ ІНВАРІАНТНОСТІ ДЛЯ ПОСТСОЦАЛІСТИЧНИХ КРАЇН}

Дослідження демократії є важливим для розуміння процесів, які відбуваються в кожній краӥні. Водночас аналіз динаміки цуих змін не є ефективним і деталізованим без оцінки подібності та стійкості вимірювальних конструктів. Для крос-національного порівняння изінностей необхідно враховувати інваріантність икал, які використовуються. Метою даної статті $\epsilon$ огляд методологічної проблеми вимірювання інваріантності, зокрема шкал демократичних цінностей. Ця стаття включає в себе підходи вивчення поняття демократичних цінностей, узагальненого визначення поняття иінностей демократичних орієнтацій та їх компонентів. Огляд літератури дає можливість окреслити методологічну проблему та запропонувати власне бачення подальшого ії дослідження.

Ключові слова: демократія, демократичні чінності, вимірювання інваріантності, багатогруповий конфірматорний факторний аналіз.

Нагорняк E.H., аспирант кафедры социологии Национального университета «КиевоМогилянская академия», специалист по управлению проектами ОО «Украинский институт социальных исследований имени А. Яременко» (Киев)

\section{ШКАЛЫ ДЕМОКРАТИЧЕСКИХ ЦЕННОСТЕЙ: ИЗМЕРЕНИЕ ИНВАРИАНТНОСТИ ДЛЯ ПОСТСОЦИАЛИСТИЧЕСКИХ СТРАН}

Исследование демократии важно для понимания проиеессов, происходящиих в каждой стране. В то же время анализ динамики этих изменений не является эффективным и детализированным без оценки сходства и устойчивости измерительных конструктов. Для кросс-национального сравнения ценностей необходимо учитывать инвариантность используемых шкал. Целью данной статьи является обзор методологической проблемы измерения инвариантности, $в$ частности шкал демократических иееностей. Эта статья включает в себя подходы изучения понятия демократических иенностей, обобщенного определения понятия ценностей демократических ориентаций и их компонентов. Обзор литературы позволяет выделить методологическую проблему и предложить своё видение дальнейшего её исследования.

Ключевые слова: демократия, демократические иенности, измерения инвариантности, многогрупповой конфирматорный факторный анализ. 